\title{
Юлія Котелянець,
}

кандидат педагогічних наук, старший викладач кафедри методик дошкільної та початкової освіти, Центральноукраїнський державний педагогічний університет імені Володимира Винниченка (м. Кропивницький, Україна)

\section{Yuliia Kotelianets,}

Candidate of pedagogical sciences (PHD), senior teacher of the chair of methodics of pre-school and primary school education, Central Ukrainian State Pedagogical University (Kropyvnytskyi, Ukraine)

Удк 373.2.016:62

\section{ФОРМУВАННЯ ТВОРЧОЇ АКТИВНОСТІ ДІТЕЙ СТАРШОГО ДОШКІЛЬНОГО ВІКУ В ПРОЦЕСІ ІНТЕГРАЦІЇ МОВЛЕННЄВОЇ ТА ОБРАЗОТВОРЧОЇ ДІЯЛЬНОСТІ}

\begin{abstract}
Анотація. У статті зрозглядаються теоретичні аспекти формування творчої активності дітей старшого дошкільного віку, зокрема, акцентується увага на інтеграції образотворчих видів діяльності й розвитку мовлення. На основі аналізу досліджень уточнено сутність поняття «творча активність»; акцентовано увагу, що одним з показників розвитку творчої активності особистості $€$ цілісність сприйняття дітьми творів мистецтва. Встановлено, що організація процесу формування творчої активності неможлива без опори на різні види діяльності дітей дошкільного віку: розвиток зв'язного мовлення, словотворчість, образотворча та конструктивна діяльність тощо. Запропоновано ряд складових, які забезпечать ефективність організації освітнього процесу закладів дошкільної освіти (ЗДО) 3 метою формування творчої активності дітей старшого дошкільного віку.

Ключові слова: творча активність, діти старшого дошкільного віку, творчість, образотворча діяльність, інтеграційні процеси, мовленнєва діяльність.

\section{FORMATION OF CREATIVE ACTIVITY OF OLDER PRESCHOOL CHILDREN IN THE PROCESS OF INTEGRATION OF SPEECH AND VISUAL ACTIVITY}

Abstract. The article reveals theoretical aspects of the formation of older preschool children's creative activity, attention is paid to the integration of visual activity and development of speech. On the basis of research analysis the essence of the concept "creative activity" is clarified. Analyzing psychological and pedagogical research of creativity as a whole, summarizing the experience of scientists and teachers - practitioners on the formation of creative activity, we came to the conclusion that creative activity of older preschool children is an active state of personality, characterized by the desire to transform something, creation of personally significant material or spiritual product.

It is emphasized that one of the indicators of the development of creative activity of the individual is the integrity of the children's perception of works of art. It is established that organization of the process of forming creative activity is impossible without reliance on various activities of preschool children: development of coherent speech, word creation, decorative and constructive activity, etc.

A number of components that will ensure the effectiveness of organizing the educational process in the kindergarden with the aim of forming the creative activity of older preschool children have been proposed. In our opinion, the formation of creative activity of older preschool children will be more effective if:

1. Use predominantly integrated classes on the stage of reinforcement of the main material.

2. The creative approach of the teacher will provide variation in the usage of teaching methods, tools and techniques.

3. Use in addition to traditional some unusual materials for children's creativity.

4. Using a variety of descriptive language (the language of literature, nature, art, music, etc.), creative problematic situations stimulate not so much external as internal creative activity (sensory and mental actions).

In this way, a holistic approach is provided, the aim of which is a child himself, his worldperseption, feeling and understanding of the world.. It is not direct learning, but the awakening of the child's internal reserves to the transformation of knowledge, the stimulation of the hidden lines of individual development that can transform knowledge from a purpose into a means of development of the person - creator.

Keywords: creative activity, preschool children, creativity, visual activity, integrative processes, speech activity. 


\section{ВСТУП}

Постановка проблеми. Проблема розвитку творчо активної особистості, здатної самостійно творити, нестандартно мислити, винаходити, є однією із значущих в сучасній педагогіці й гостро стоїть перед суспільством.

У Концепції дошкільної освіти підкреслюється необхідність розвитку різних видів активності дітей, а також відзначено, що зміст освіти має бути орієнтований на організацію видів діяльності, що стимулюють розвиток мислення, уяви, фантазії й дитячої творчості, реалізацію творчої діяльності дітей. За допомогою розвитку основного компонента творчих здібностей - творчої активності, можна досягти цієї мети.

Мистецтво є унікальним засобом формування найважливіших сторін психічного життя дітей - емоційної сфери, образного мислення, уяви, художніх і творчих здібностей.

Аналіз наукових досліджень і публікацій. Основу для розуміння природи особистісного становлення в дошкільному дитинстві склали праці сучасних дослідників Г. Бєлєнької, А. Богуш, Н. Гавриш, О. Ковшар, О. Кононко, В. Котирло, О. Кочерги, С. Кулачківської, О. Кучерявого, Ю. Приходько, О. Проскури тощо.

Психологічні аспекти проблеми формування творчої активності дітей дошкільного віку представлені в роботах Б. Ананьєва, Л. Виготського, Є. Ігнатьєва, Д. Колесова, Г. Урунтаєвої тощо. Педагогічні аспекти художньо-творчого розвитку дошкільників викладаються в працях Н. Ветлугіної, О. Дронової, Т. Казакової, Т. Комарової, О. Радинової, Н. Сакуліної, Є. Фльориної, Н. Халєзова, Т. Шпікалової тощо.

\section{МЕТА І ЗАВДАННЯ ДОСЛІДЖЕННЯ}

Мета статті - розкрити теоретичні аспекти проблеми формування творчої активності дітей старшого дошкільного віку в процесі інтеграції мовленнєвої та образотворчої діяльності.

\section{РЕЗУЛЬТАТИ ДОСЛІДЖЕННЯ}

Творча активність - це складна інтегральна якість особистості, що характеризує діяльність людини, спрямовану на вирішення творчих завдань, орієнтованих на використання можливостей особистості, результатом якої $є$ певна новизна, значимість для особистісного зростання.

Аналізуючи психолого-педагогічні дослідження з проблем творчості в цілому, узагальнюючи досвід учених і педагогів-практиків з питань формування творчої активності, ми дійшли до висновку, що творча активність дітей старшого дошкільного віку є діяльнісним станом особистості, що характеризується прагненням до перетворення чого-небудь, створення особистісно значущого матеріального або духовного продукту.

Організація даного процесу неможлива без опори на різні види діяльності дітей дошкільного віку: розвиток мовлення, словотворчість, образотворча та конструктивна діяльність тощо.

Згідно з дослідженнями, важливу роль в творчому процесі дітей дошкільного віку відіграє взаємозв'язок образотворчих видів діяльності й розвитку мовлення (А. Богуш, Н. Гавриш, О. Борисовська, Л. Колунова, Т. Комарова, Ю. Полуянов тощо).

Проблема залежності образотворчої діяльності дітей дошкільного віку від розвитку їх мовлення була поставлена ще на початку XX століття і з тих пір є традиційною для психолого-педагогічних досліджень (А. Бакушинський, I. Будницька та інші). Вченими стверджувалося, що процес образотворчої діяльності дітей завжди включає словесну розповідь, зображення окремих предметів пов'язано із значенням слова, що малюнок дитини без словесного пояснення часто виявляється незрозумілим оточуючим.

Найважливішою ознакою виразності художнього твору є зв'язки між різними його елементами (Р. Арнхейм, М. Волков та інші). У дитячому малюнку такими «елементами» можуть служити зображення окремих істот, предметів, тому що саме окремі зображення виявляються для дитини тією «одиницею», з якою вона діє в малюнку (Г. Бабунська). Зв'язки між елементами можуть виражатися через їх розміщення на аркуші й передачу в малюнку рухів і станів об'єктів. Подібні зв'язки, як вказують Ю. Полуянов, О. Борисовська, можуть міститися й в словесній інтерпретації малюнка, особливо в оповіданні-задумі, що передує процесу зображення. Співвідношення вербальних й образотворчих зав'язків в малюнку розкриває залежність між мовленням і виразністю малюнків (Полуянов Ю., Борисовська О., 1980).

3 метою успішного розвитку виразності дитячого малюнка, формування творчої активності, педагогу, на думку Л. Компанцевої, О. Сомкової, необхідно використовувати вербальні зв'язки (Сомкова О.Н., 2000). Найбільш ефективними в цьому плані є поетичні твори, усна народна творчість.

Поетичний образ має дві взаємопов'язані сторони в дитячій образотворчій діяльності: образотворчу й виразну. Образотворчість художнього слова - це його здатність викликати конкретні, зримі образи, представити їх образотворчі якості - колір, форму, пропорції, розташування в загальній картині, деталі. Створені в уяві слухачами живі образи викликають ряд інших образів, які безпосередньо не зображені в творі, тобто художній образ сприяє виробленню асоціацій. Г. Рижова відзначила роль художньо-асоціативних полів у формуванні творчої активності дітей. Залучення різних видів мистецтва, на думку автора, здатне виявити в дитині широке коло асоціацій, пов'язаних як з її життєвим, так і культурним досвідом. Художньо-естетичні асоціації і паралелі надають індивідуальне емоційне й естетичне забарвлення майбутньому твору (Рыжова Н.А., 2001).

Виразність художнього слова полягає у виділенні головного в образі, узагальненні істотних ознак. Завдяки цьому образ стає відчутним, конкретним, його можна перенести на папір, полотно. До виразних засобів поетичних творів відносяться метафори, порівняння, епітети тощо. Через розуміння образного порівняння дитина приходить до самостійного їх створення.

Художні твори впливають на думки та почуття дитини за допомогою образності. Накопичення дитиною неусвідомленої словесної інформації, позбавленої природного зв'язку з почуттями, емоційно-образною пам'яттю, уявою, мисленням, перетворює дитячу психіку в примітивний механізм. Так, О. Сомкова доводить, що в старшому дошкільному віці важливим засобом розвитку творчої активності в мовній діяльності стає опанування образними порівняннями. Навчання дітей вмінню знаходити порівняння в готових літературних творах, самостійно створювати образні порівняння повинно, на думку автора, носити комплексний характер (Сомкова О.Н., 2000). 
Комплексність проявляється як у формі організації навчання (заняття, гри, спостереження), так і в засобах навчання (література, образотворча та конструктивна діяльність тощо).

Одним із показників розвитку творчої активності особистості, на думку вчених, є цілісність сприйняття дітьми творів мистецтва, під якою розуміється інтеграція форми й змісту (Л. Бабуцька, 1992). Роль мистецтва, в цілому, визначена його функціями. Виходячи з основних видів діяльності, М. Каган виокремив чотири основні функції мистецтва (Каган М., 1996):

1. Пізнавальна. Мистецтво розширює знання дитини про життя, додаючи до її власного досвіду багатий досвід художника, письменника, композитора, які закріплюються в моральних нормах, політичних ідеях, наукових знаннях.

2. Виховна. Виховний вплив музики, живопису, літератури можна з успіхом використовувати в процесі формування активності особистості. За словами В. Сухомлинського, виховна сила мистецтва ґрунтується на тому, що воно змушує людей себе перевиховувати, відчуваючи й переживаючи те, що не довелося їм випробувати й пережити в житті (Сухомлинський В., 1980).

3. Гедоністична. Мистецтво містить в собі не тільки художню, а й специфічну інформацію про творчість й майстерність художника, письменника, композитора.

4. Комунікативна. Роль мистецтва як засобу спілкування полягає в тому, що: а) мова мистецтва доступна розумінню всього людства; б) емоційна насиченість художнього образу дозволить глибше проникнути в душі людей; в) воно здатне об'єднати людей на такому духовному рівні, який не підвладний мовній та іншій комунікації.

На сучасному етапі мистецтву притаманна ще одна - моделювальна функція. Зокрема, Р. Чумічова вказує, що мистецтво здатне створити модель світу й людини в ньому, розкрити «таємницю» культури. Цим викликана необхідність співіснування різних видів мистецтва, тому що жодне з них окремо не може дати досить повну картину світу. Засобом їх об'єднання, на думку автора, є синтез (Чумичева Р.М., 1998, с. 16).

У зв'язку з цим Р. Чумічова й ряд інших дослідників вказують на необхідність створення інтегрованої програми художньо-естетичного розвитку дітей дошкільного віку, основою якої був би синтез трьох видів мистецтва: живопису, музики, літератури. Метою створеної Р. Чумічовою та іншими дослідниками програми є: формування субкультури дитини, що розуміється як єдність її естетичних смаків, моральних позицій, пізнавального розвитку. Для досягнення даної мети автор пропонує використовувати можливі варіанти синтезу мистецтв:

1) на основі загальнолюдських цінностей (культурно-пізнавальних, гуманістичних, моральних, естетичних);

2) на основі загального для різних видів мистецтв змісту, який, у свою чергу, групується наступним чином:

- світ людини (його внутрішня сутність, особисті та соціальні зв'язки, ставлення до природи й предметного світу тощо);

- світ природи (ї̈ краса, гармонія, стан природи, її взаємозв'язок з людиною, тобто вплив природи на стан людини та її ставлення до неї, місце людини в природі тощо);

- світ предметів (способи взаємодії людини з предметами, відображення в предметах характеру епохи й традицій народу, краса предметів, їх призначення тощо).

3) на основі загальних для різних видів мистецтв зображувально-виражальних засобів, таких як: композиція, ритм, темп, повтори, тон, світло, мелодія кольору тощо (Чумичева Р.М., 1998).

Створення цієї програми спрямовано на впровадження культури в освітньо-виховний процес закладу дошкільної освіти. Художня культура є феноменом педагогічного процесу й має значний вплив на формування духовного життя дитини, розвиток її інтелектуальних і творчих здібностей, формування творчої активності.

А. Богуш, Н. Гавриш, Т. Котик розроблено методику організації художньо-мовленнєвої діяльності дітей у закладах дошкільної освіти, розкрито різні види художньо-мовленнєвої діяльності: театралізовану, образотворчомовленнєву, музично-мовленнєву, а також подано методику спільної роботи закладу дошкільної освіти й сім'ї з художньо-мовленнєвої діяльності (Богуш А., Гавриш Н., Котик Т., 2006).

Отже, впровадження інтеграційних процесів, на наш погляд, - одна з про-прогресивних тенденцій сучасної дошкільної освіти. Наявний у дошкільній теорії та практиці досвід показує ефективність створення інтегрованих програм, систем занять, побудованих на інтегративно-тематичній основі (Е. Болотова, І. Будакова, Л. Кларін, Н. Курочкіна, О. Луннік, І. Максимова, Н.Трифонова, С.Шабаліна, Р. Чумічова тощо).

Цілісні, художньо-образні методи пізнання властиві емоційно-образній природі мистецтва й спираються переважно на синтез, представлені в дошкільному закладі недостатньо. Адже постійна апеляція до розуму, недовантаження емоційно-образної сфери притупляють гостроту чуттєвого сприйняття, інтуїцію і деформують досвід дитини. Творча активність з віком згортається та згасає.

За педагогічно доцільної організації діяльності дитини дорослими вона здатна відчути себе першовідкривачем, випробувати радість експериментування з об'єктами живої та неживої природи, відкрити нове у знайомому й знайти знайоме в новому; виокремити найпростіші закономірності, усвідомити їх непорушний характер та все ж спробувати змінити його, використовуючи для цього весь творчий потенціал.

Саме тому актуальною є проблема формування творчо активної особистості вже на етапі дошкільного дитинства, виховання людини, яка вміє творчо використовувати свої знання, займати самостійну позицію стосовно зовнішніх умов.

Тріада компонентів творчої активності підкреслює її складний інтегративний характер. Тому під час розробки технології формування творчої активності дітей старшого дошкільного віку необхідна опора на розвиток показників мотиваційного, креативного та інтелектуального компонентів. В основу даної технології доцільно включити інтеграцію змістовної і діяльнісної сторін освітнього процесу ЗДО. Це, на наш погляд, дозволить:

об'єднати в досягненні єдиної мети раніше розрізнені галузі знань і, тим самим, підвищити мотиваційну спрямованість творчої активності дітей. Зокрема, інтеграція мовленнєвої та образотворчої діяльності відкриває можливість стимулювання інтересу, допитливості, ініціативи й самостійності дошкільників і майбутньої творчості; 
- урізноманітнювати зміст дитячих робіт; використовувати поряд з традиційними незвичайні матеріали й види творчої діяльності дітей з метою вдосконалення креативних показників творчої активності. Так, включення в творчість дітей покидькових (пластикові пляшки, кришки тощо), природних (черепашки, солома, листя тощо) матеріалів, оригінальне їх комбінування з уже відомими (пластилін, папір, фарби тощо) дає можливість старшим дошкільникам створювати неординарні творчі роботи;

- розглядати певну тему у взаємозв'язку елементів змісту, видів діяльності, що забезпечить цілісне бачення предмета (явища).

ВИСНОВКИ ТА ПЕРСПЕКТИВИ ПОДАЛЬШИХ ДОСЛІДЖЕНЬ

Формування творчої активності як вольового акту передбачає певну організацію освітнього процесу. На наш погляд, формування творчої активності дітей старшого дошкільного віку буде більш ефективним, якщо: 1) використовувати переважно інтегровані заняття на етапі закріплення основного змісту; 2) творчий підхід педагога забезпечить варіювання у використанні методів, засобів і прийомів навчання; 3) використовувати поряд з традиційними незвичайні матеріали для творчості дітей; 4) за допомогою різноманітної мови опису (мова літератури, природи, мистецтва, музики тощо), творчих проблемних ситуацій стимулювати не стільки зовнішню, скільки внутрішню творчу активність (сенсорні та розумові дії).

Таким чином забезпечиться цілісний підхід, метою якого є сама дитина, її світосприйняття, світовідчуття, світорозуміння. Не пряме навчання, а пробудження внутрішніх резервів дитини до перетворення знань, стимулювання прихованих ліній індивідуального розвитку здатне перетворити знання з мети на засіб розвитку Людини-творця.

\section{СПИСОК ВИКОРИСТАНИХ ДЖЕРЕЛ}

Бабуцкая, Л.А. (1992). О взаимоотношениях интеллектуальных и эмоциональных компонентов в художественной деятельности школьников. Игра. Творчество. Одаренность: Тезисы докладов науч.-практ. семинара при НИИ ХВАПН СССР. М.: Росстани, 109.

Богуш, А., Гавриш, Н., Котик, Т. (2006). Методика організації художньо-мовленнєвої діяльності дітей у дошкільних навчальних закладах: Підручник для студентів вищих навчальних закладів факультетів дошкільної освіти. К.: Видавничий Дім «Слово», 304.

Каган М.С. (1996). Философия культуры. акад. Гуманитар. Наук; Спб. Гуманитар. Ун-т профсоюзов; Спб. Гос. Ун-т. - Спб. : Петрополис, 415 с

Комарова, Т.С. (1990). Изобразительная деятельность в детском саду. М.: Педагогика, 1990.

Лабунская, Г.В. (1965). Изобразительное творчество детей. М.: Просвещение, 203.

Полуянов, Ю.Н., Борисовская, О.Б. (1980). Соотношение вербального и изобразительного в содержании детского рисунка. Психология формирования личности и проблемы обучения: Сб.науч.тр. Под ред. Д.Б. Эльконина, И.В.Дубровиной. М., 29.

Ребенок в мире культуры (1998). Под ред. Р.М. Чумичевой. Ставрополь: Ставропольсервисшкола.

Рыжова, Н.А. (2001). Экологическое образование в детском саду. М.: Изд. Дом «Карапуз», 432.

Рюмина, Ю.Н. (2001). Изучение возможностей формирования творческой активности дошкольников в процессе интегрированного обучения. Инновационные технологии в системе дошкольного образования: Мат-лы российск. науч.-практ.конф. Курган: Главное управление образования.

Сомкова, О.Н. (2000). Развитие творческой речевой активности ребенка 5-6 лет в процессе освоения средств языковой выразительности. Воспитываем дошкольников самостоятельными: Сб.статей РГПУ им. А.И. Герцена. СПб.: Детство-пресс, 45.

Сухомлинський В. О. (1980). Вибрані твори: в 5-ти т. К.: Радянська школа, Т. 5. 678 с.

\section{REFERENCES}

Babutskaja, L.A. (1992). O vzaymootnoshenyiakh intellektualnykh i emotsyonalnykh komponentov v khudozhestvennoi deiatelnosti shkolnykov (About the relations between intellectual and emotional components in the artistic activity of schoolchildren). Ihra. Tvorchestvo. Odarennost: Tezysy dokladov nauch.-prakt. semynara pry NYY KhVAPN SSSR. M.: Rosstany, 109.

Bohush, A., Havrysh, N., Kotyk, T. (2006). Metodyka orhanizatsii khudozhno-movlennievoi diialnosti ditei u doshkilnykh navchalnykh zakladakh: Pidruchnyk dlia studentiv vyshchykh navchalnykh zakladiv fakultetiv doshkilnoi osvity. (Methods of organizing children's artistic and speech activities in preschool institutions: A textbook for students of higher education faculties of pre-school faculties). K.: Vydavnychyi Dim «Slovo», 304.

Kagan, M.S. (1996). Fylosofyia kultury. (Philosophy of culture). Humanytar. Un-t profsoiuzov; Spb. Hos. Un-t. - Spb. : Petropolys, $415 \mathrm{~s}$

Komarova, T.S. (1990). Yzobrazytelnaia deiatelnost v detskom sadu.(Fine art activities in kindergarten). M.: Pedaho-hyka.

Labunskaia, H.V. (1965). Izobrazytelnoe tvorchestvo detej( Children's fine art). M.: Prosveshchenye, 203.

Poluianov, Yu.N., Borysovskaia, O.B. (1980). Sootnoshenye verbalnoho y yzobrazytelnoho v soderzhanyy detskoho rysunka (The relation between verbal and artistic content of children's drawing). Psykholohyia formyrovanyia lychnosty y problemy obuchenyia: Sb.nauch.tr. Pod red. D.B. Elkonyna, Y.V.Dubrovynoi. M., 29.

Rebenok v myre kultury (The child in the world of culture). (1998). Pod red. P.M. Chumychevoi. Stavropol: Stav-ropolservysshkola.

Ruzhova, N.A. (2001). Ekolohycheskoe obrazovanye v detskom sadu. (Environmental education in kindergarten). M.: Yzd. Dom «Karapuz», 432

Riumyna, Yu.N. (2001). Yzuchenye vozmozhnostei formyrovanyia tvorcheskoi aktyv-nosty doshkolnykov v protsesse yntehryrovannoho obuchenyia (Studying possibilities preschool children's formation of creative activity of in the process of integrated learning).Ynnovatsyonnue tekhnolohyy v systeme doshkolnoho obrazovanyia: Matlu rossyisk. nauch.-prakt.konf. Kurhan: Hlavnoe upravlenye obrazovanyia.

Somkova, O.N. (2000). Razvytye tvorcheskoi rechevoi aktyvnosty rebenka 5-6 let $v$ protsesse osvoenyia sredstv yazukovoi vurazytelnosty (Development of creative speech activity of the child of 5-6 years in the process of development of means of language expression). Vospytuvaem do-shkolnykov samostoiatelnumy: Sb.statei. RHPU ym. A.Y. Hertsena. SPb.: Detstvo-press, 45.

Sukhomlinsky, V.O. (1980) Vybrani tvory: v 5-ty (Selected works: in 5 volumes). K.: Radianska shkola, T. 5. 678 s.

Статтю подано до редколегії Рекомендовано до друку
12.04.2020 p

$02.05 .2020 p$ 